\title{
Ethylene Inhibitors Enhance Shoot Organogenesis of Gloxinia (Sinningia speciosa)
}

\author{
Soo Cheon Chae, ${ }^{1}$ Haeng Hoon Kim, ${ }^{2}$ and Sang Un Park ${ }^{3}$ \\ ${ }^{1}$ Department of Horticultural Science, College of Industrial Sciences, Kongju National University, 1 Daehoe-ri, Yesan-kun, \\ Chungnam 340-720, Republic of Korea \\ ${ }^{2}$ Department of Well-Being Resources, Sunchon National University, 413 Jungangno, Suncheon, \\ Jeollanam-do 540-742, Republic of Korea \\ ${ }^{3}$ Department of Crop Science, College of Agriculture and Life Sciences, Chungnam National University, \\ 99 Daehangno, Yuseong-gu, Daejeon 305-764, Republic of Korea
}

Correspondence should be addressed to Sang Un Park, supark@cnu.ac.kr

Received 2 August 2012; Accepted 23 September 2012

Academic Editors: Y. Shoyama and R. B. Widelitz

Copyright ( 92012 Soo Cheon Chae et al. This is an open access article distributed under the Creative Commons Attribution License, which permits unrestricted use, distribution, and reproduction in any medium, provided the original work is properly cited.

Shoot organogenesis and plant regeneration in Sinningia speciosa were improved using ethylene inhibitors. The leaf explants were cultured on initial shoot regeneration media (MS media with BAP at $2 \mathrm{mg} / \mathrm{L}+\mathrm{NAA}$ at $0.1 \mathrm{mg} / \mathrm{L}$ ) supplemented with different concentrations of aminoethoxyvinylglycine (AVG), cobalt chloride $\left(\mathrm{CoCl}_{2}\right)$, and silver thiosulphate (STS). The addition of AVG, $\mathrm{CoCl}_{2}$, and STS significantly improved the regeneration frequency giving higher shoots per explant and longer shoot length. The highest shoot growth was found when STS at $5 \mathrm{mg} / \mathrm{L}$ was incorporated with generation medium, performing highest regeneration frequency with highest number of shoots. This treatment (STS at $5 \mathrm{mg} / \mathrm{L}$ ) produced $40 \%$ more shoots per explant compared to control followed by STS at $10 \mathrm{mg} / \mathrm{L}$ with increasing $37 \%$ more shoots compared to control. In the cases of $\mathrm{AVG}$ and $\mathrm{CoCl}_{2}$ the highest shoot number per explant was found at $1 \mathrm{mg} / \mathrm{L}$. Treated with AVG and $\mathrm{CoCl}_{2}$ at $1 \mathrm{mg} / \mathrm{L}$ increased shoot number by 16 and $12 \%$, respectively, compared to control. Ethylene inhibitors could be used as a possible micropropagation and plant transformation protocol in S. speciosa for plant regenerations.

\section{Introduction}

Sinningia speciosa Baill, commonly known in the horticultural trade as gloxinia, is a tuberous member of the flowering plant family Gesneriaceae. The common name has persisted since its original introduction to cultivation from Brazil in 1817 as Gloxinia speciosa. The name florist's gloxinia is sometimes used to distinguish it from the rhizomatous species now included in the genus Gloxinia. This species produces single or double flowers with a variety of colors. Generally its propagation can be done by leaf, stem, rhizome, seed, and crown cuttings from a mature plant after blooming. It takes approximately 6 to 7 months for commercial production of a blooming gloxinia $[1,2]$.

Successful shoot organogenesis technique for plant regeneration depends on the proper establishment of medium components, a suitable explant, and control of the physical environment $[3,4]$. One of the most important factors of physical environment in plant tissue culture is ethylene $\left(\mathrm{C}_{2} \mathrm{H}_{4}\right)$, a gaseous plant hormone that plays an important role in plant growth and development [5]. Same research was done in the past using ethylene inhibitors, that is, aminoethoxyvinylglycine (AVG), cobalt chloride $\left(\mathrm{CoCl}_{2}\right)$, benzyl isothiocyanate (BITC), aminocarboxypropionic acid, 1-methylcyclopropene (1-MCP), polyamines, silver nitrate $\left(\mathrm{AgNO}_{3}\right), 3,4,5$-trichlorophenol, salicylic acid (2-hydroxybenzoic acid), and silver thiosulphate (STS), for promoting shoot organogenesis in several plant species which has been reviewed by Kumar et al. [6]

Recently some studies especially for in vitro plant regeneration were done in gloxinia using leaf explant culture [7-10] and even direct regeneration of floral buds from sepal segments has been reported $[11,12]$. In this paper, 
we report the establishment of an improved method for plant regeneration from the leaf explants of S. speciosa. We examined for the first time the influence of ethylene inhibitors (STS, AVG, and $\mathrm{CoCl}_{2}$ ) on shoot organogenesis of S. speciosa.

\section{Materials and Methods}

2.1. Plant Material. Seeds of Sinningia speciosa were surfacesterilized with $70 \%(\mathrm{v} / \mathrm{v})$ ethanol for $1 \mathrm{~min}$ and $2 \%(\mathrm{v} / \mathrm{v})$ sodium hypochlorite solution for $10 \mathrm{~min}$, then rinsed three times in sterilized water. Five seeds were placed on $25 \mathrm{~mL}$ of agar-solidified culture medium in Petri dishes $(100 \times$ $15 \mathrm{~mm}$ ). The basal medium consisted of salts and vitamins of MS [13] medium and solidified with $0.7 \%$ (w/v) agar. The medium was adjusted to $\mathrm{pH} 5.8$ before adding agar and then sterilized by autoclaving at $121^{\circ} \mathrm{C}$ for $20 \mathrm{~min}$. The seeds were germinated in a growth chamber at $25 \pm 1^{\circ} \mathrm{C}$ under standard cool white fluorescent tubes with a flux rate of $35 \mu \mathrm{mol}$ $\mathrm{s}^{-1} \mathrm{~m}^{-2}$ and a $16-\mathrm{h}$ photoperiod.

2.2. Shoot Organogenesis. Young leaves of Sinningia speciosa were taken from in vitro grown plants. Leaves were cut aseptically at the ends, into sections of approximately $7 \times$ $7 \mathrm{~mm}^{2}$ in size. Explants were placed on the MS medium and solidified with $0.3 \%$ (w/v) Gelrite. Seven explants were cultured in each Petri dish. The $\mathrm{pH}$ of medium was adjusted to 5.8 before adding Gelrite. The media were sterilised by autoclaving at $1.1 \mathrm{~kg} \mathrm{~cm}^{-2}\left(121^{\circ} \mathrm{C}\right)$ for $20 \mathrm{~min}$. Previously, we established gloxinia shoot induction medium consisting of MS salts and vitamins, $30 \mathrm{~g} / \mathrm{L}$ sucrose, $3 \mathrm{~g} / \mathrm{L}$ Gelrite, $2 \mathrm{mg} / \mathrm{L}$ 6-benzylaminopurine (BAP), and $0.1 \mathrm{mg} / \mathrm{L}$ NAA (1-naphthalene-acetic acid) [10]. For improvement of shoot regeneration of gloxinia, the shoot induction medium was optimized by testing the effect of different concentrations of ethylene inhibitors $(0,1,5,10$, and $20 \mathrm{mg} / \mathrm{L}$ aminoethoxyvinylglycine, cobalt chloride, and silver thiosulphate). Cultures were maintained at $25 \pm 1{ }^{\circ} \mathrm{C}$ in a growth chamber with a 16 -h photoperiod under standard cool white fluorescent tubes $\left(35 \mu \mathrm{mol} \mathrm{s} \mathrm{s}^{-1} \mathrm{~m}^{-2}\right)$ for 6 weeks.

2.3. Rooting and Acclimatization of Regeneration Plants. Regenerated shoots (around $1 \mathrm{~cm}$ long) were placed in MS medium. The medium was solidified with $3 \mathrm{~g} / \mathrm{L}$ Gelrite and dispensed at $30 \mathrm{~mL}$ per Magenta box and four shoots were cultured in each box. Regenerated shoots were incubated at $25 \pm 1^{\circ} \mathrm{C}$ in a growth chamber with a 16 -h photoperiod under standard cool white fluorescent tubes $\left(35 \mu \mathrm{mol} \mathrm{s}{ }^{-1} \mathrm{~m}^{-2}\right)$ for 5 weeks. After five weeks, the rooted plants were washed with tap water to remove Gelrite, transferred to pots containing autoclaved vermiculite, and covered with polyethylene bags for one week to maintain high humidity. The plants were then transferred to soil and maintained in a growth chamber with a 16-h photoperiod, and a night/day temperature of $18 / 20^{\circ} \mathrm{C}$ for 2 weeks. These hardened plants were then transferred to the greenhouse.
TABLE 1: Effect of different concentrations of ethylene inhibitors on on shoot regeneration and growth from leaf cultures of Sinningia speciosa after 6 weeks in culture on regeneration medium (MS medium with $2.0 \mathrm{mg} / \mathrm{L} \mathrm{BA}$ and $0.1 \mathrm{mg} / \mathrm{L} \mathrm{NAA}$ ).

\begin{tabular}{|c|c|c|c|c|}
\hline \multicolumn{2}{|c|}{$\begin{array}{l}\text { Ethylene inhibitors* } \\
\left(\mathrm{mg} \mathrm{L}^{-1}\right)\end{array}$} & \multirow{2}{*}{$\begin{array}{c}\text { Regeneration } \\
\text { frequency** } \\
(\%)\end{array}$} & \multirow{2}{*}{$\begin{array}{l}\begin{array}{c}\text { Number of } \\
\text { shoots per } \\
\text { explant** }\end{array} \\
12.3 \pm 0.8 \\
\end{array}$} & \multirow{2}{*}{$\begin{array}{c}\begin{array}{c}\text { Shoot length } \\
(\mathrm{cm})\end{array} \\
1.21 \pm 0.1 \\
\end{array}$} \\
\hline Control & 0 & & & \\
\hline \multirow{4}{*}{ AVG } & 1 & 85 & $14.3 \pm 1.2$ & $1.23 \pm 0.2$ \\
\hline & 5 & 75 & $13.5 \pm 0.9$ & $1.6 \pm 0.2$ \\
\hline & 10 & 64 & $10.6 \pm 0.7$ & $1.8 \pm 0.2$ \\
\hline & 20 & 58 & $8.2 \pm 0.4$ & $1.1 \pm 0.1$ \\
\hline \multirow{4}{*}{$\mathrm{CoCl}_{2}$} & 1 & 79 & $13.8 \pm 0.7$ & $1.36 \pm 0.1$ \\
\hline & 5 & 72 & $11.8 \pm 0.9$ & $1.18 \pm 0.1$ \\
\hline & 10 & 62 & $9.2 \pm 0.6$ & $0.85 \pm 0.1$ \\
\hline & 20 & 45 & $5.9 \pm 0.4$ & $0.57 \pm 0.1$ \\
\hline \multirow{4}{*}{ STS } & 1 & 77 & $13.1 \pm 0.9$ & $1.18 \pm 0.1$ \\
\hline & 5 & 91 & $17.2 \pm 1.6$ & $1.27 \pm 0.2$ \\
\hline & 10 & 89 & $16.8 \pm 1.2$ & $1.25 \pm 0.2$ \\
\hline & 20 & 63 & $11.4 \pm 0.8$ & $0.84 \pm 0.1$ \\
\hline
\end{tabular}

\section{Results}

Recently an improved and effective method for the in vitro plant regeneration of $S$. speciosa was reported by Park et al. [10]. We established optimal medium for plant regeneration of $S$. speciosa including BAP $(2 \mathrm{mg} / \mathrm{L})$ and NAA $(0.1 \mathrm{mg} / \mathrm{L})$ resulting in the highest efficiency in shoot regeneration per explant and in the greatest shoot growth. For investigating the influence of ethylene inhibitors on shoot regeneration of S. speciosa, the leaf explants were cultured on initial shoot regeneration media (MS media supplemented with BAP at $2 \mathrm{mg} / \mathrm{L}+\mathrm{NAA}$ at $0.1 \mathrm{mg} / \mathrm{L})$ that included $0,1,5,10$, and $20 \mathrm{mg} / \mathrm{L}$ aminoethoxyvinylglycine (AVG), cobalt chloride $\left(\mathrm{CoCl}_{2}\right)$, and silver thiosulphate (STS).

The addition of $\mathrm{AVG}, \mathrm{CoCl}_{2}$, and STS significantly improved the regeneration frequency giving higher shoots per explants and longer shoot length (Table 1). Shoot growth increased with increasing concentrations of STS up to $5 \mathrm{mg} / \mathrm{L}$, but thereafter decreased as the concentrations increased. In this study, the highest shoot growth was found when the generation medium (MS media with BAP at $2 \mathrm{mg} / \mathrm{L}+\mathrm{NAA}$ at $0.1 \mathrm{mg} / \mathrm{L}$ ) was supplemented with STS at $5 \mathrm{mg} / \mathrm{L}$, performing $91 \%$ regeneration frequency with highest number of shoots (17.2) in each explant (Table 1). This treatment (STS at $5 \mathrm{mg} / \mathrm{L}$ ) produced $40 \%$ more shoot per explant compared to control. STS at $10 \mathrm{mg} / \mathrm{L}$ produced the second highest shoot number (16.8) that represents $37 \%$ more shoots compared to control (Table 1). The shoot number from each explant was 25 and 20\% higher at STS at $5 \mathrm{mg} / \mathrm{L}$ compared to the treatment of AVG and $\mathrm{CoCl}_{2}$, respectively, which had the highest shoot number at $1 \mathrm{mg} / \mathrm{L}$ 
of both AVG and $\mathrm{CoCl}_{2}$ (Table 1). In the cases of AVG and $\mathrm{CoCl}_{2}$ the highest shoot number per explant was found at $1 \mathrm{mg} / \mathrm{L}$. Treated with AVG and $\mathrm{CoCl}_{2}$ at $1 \mathrm{mg} / \mathrm{L}$ increased shoot number by 16 and $12 \%$, respectively, compared to control (Table 1). Further increasing the concentration of AVG and $\mathrm{CoCl}_{2}$, the number of shoots per explant was reduced. The tallest plant was found in the treatment of $\mathrm{AVG}$ at $10 \mathrm{mg} / \mathrm{L}$, which represents $49 \%$ increase in height compared to control. To induce root formation, the regenerated shoots were transferred to MS without growth hormones. The rooting started to initiate after 3 weeks from regenerated shoots, and more than $90 \%$ of the shoots contained roots after 5 weeks. The regenerated plants which contained root were washed in tap water to remove Gelrite and transferred into pots. The plants were allowed to grow in a growth chamber at $25 \pm 1^{\circ} \mathrm{C}$ with a 16 -h photoperiod for two weeks. Pots were covered with a plastic bag to maintain high humidity conditions for two weeks. The survival rate of regenerated plants was $80 \%$ and flowered within 3 months.

\section{Discussion}

The shoot growth increased when the STS concentrations changed from $1 \mathrm{mg} / \mathrm{L}$ to $5 \mathrm{mg} / \mathrm{L}$, but thereafter decreased with increasing STS concentrations. In this study, the highest regeneration frequency $(91 \%)$ and number of shoots per explant (17.2) were observed when the regeneration medium was supplemented with STS at $5 \mathrm{mg} / \mathrm{L}$ (Table 1). This treatment produced $40 \%$ more shoots per explant compared to the control. The shoot number per explant was $25 \%$ and 20\% higher at an STS supplementation of $5 \mathrm{mg} / \mathrm{L}$ when compared to the shoot number in the presence of AVG and $\mathrm{CoCl}_{2}$, respectively, at $1 \mathrm{mg} / \mathrm{L}$. Further increases in the concentration of AVG and $\mathrm{CoCl}_{2}$ reduced the number of shoots per explant. Ethylene is produced during cell division in vitro and acts as a growth inhibitor. Further, the use of the ethylene inhibitors STS or AVG has been shown to increase the frequency of successful plant regeneration in apricot cultivars [14]. Moreover, the addition of $\mathrm{AgNO}_{3}$ and AVG to the medium was reported to markedly enhance regeneration frequency and the number of shoots per explant in Punica granatum L. [15]. The promotive effect of $\mathrm{AgNO}_{3}$, and AVG on in vitro shoot regeneration from cotyledons of Brassica campestris spp. pekinensis has also been reported [16]. During cell division in vitro ethylene is produced and it is very well known that ethylene acts as a growth inhibitor. It was reported that $\mathrm{AgNO}_{3}$ (ethylene inhibitor) inhibits the binding of ethylene during cell division [17]. Kumar et al. [6] reviewed the use of silver nitrate in plant regeneration and concluded that this chemical promoted growth of plants. Other species, including cucumber [17], Brassica [18], and coffee [19] have also been found to be affected by silver nitrate.

It is believed that plant regeneration protocols are an essential part of plant genetic transformation and lead to plant improvement. Currently, shoot organogenesis is used in in vitro plant regeneration as a most widely used method in transformation systems. This regeneration protocol has succeeded for Sinningia speciosa. The ethylene inhibitors
AVG, $\mathrm{CoCl}_{2}$, and STS significantly promoted the shoot regeneration frequency of gloxinia. These results will allow the genetic improvement of Sinningia speciosa and other flower species.

\section{References}

[1] A. Chautems, G. S. Baracho, and J. A. Siqueira Filho, "A new species of Sinningia (Gesneriaceae) from northeastern Brazil," Brittonia, vol. 52, no. 1, pp. 49-53, 2000.

[2] D. Zaitlin and A. Pierce, "Nuclear DNA content in Sinningia (Gesneriaceae); Intraspecific genome size variation and genome characterization in S. speciosa," Genome, vol. 53, no. 12, pp. 1066-1082, 2010.

[3] D. C. Brown and T. A. Thorpe, "Plant regeneration by organogenesis," in Cell Culture and Somatic Cell Genetics of Plants, I. K. Vasil, Ed., pp. 49-65, Academic Press, New York, NY, USA, 1986.

[4] T. A. Thorpe, “The current status of plant tissue culture," in Plant Tissue Culture: Applications and Limitations, S. S. Bhojwani, Ed., pp. 1-33, Elsevier, Amsterdam, The Netherlands, 1990.

[5] S. F. Yang and N. E. Hoffman, "Ethylene biosynthesis and its regulation in higher plants," Annual Review of Plant Physiology, vol. 35, no. 1, pp. 155-189, 1984.

[6] P. P. Kumar, P. Lakshmanan, and T. A. Thorpe, "Regulation of morphogenesis in plant tissue culture by ethylene," In Vitro Cellular and Developmental Biology, vol. 34, no. 2, pp. 94-103, 1998.

[7] F. Scaramuzzi, G. Apollonio, and S. D'Emerico, “Adventitious shoot regeneration from Sinningia speciosa leaf discs in vitro and stability of ploidy level in subcultures," In Vitro Cellular and Developmental Biology, vol. 35, no. 3, pp. 217-221, 1999.

[8] A. T. Nhut, N. A. Nguyet, H. T. Phuc et al., "Primary designs of tube-shaped nylon film culture system in shoot regeneration of Sinningia spp. Leaf explants," Proceedings of International Workshop on Biotechnology in Agriculture, vol. 10, pp. 131-133, 2006.

[9] Q. L. Xu, Z. Hu, C. Y. Li, X. Y. Wang, and C. Y. Wang, "Tissue culture of Sinningia speciosa and analysis of the in vitro-generated tricussate whorled phyllotaxis (twp) variant," In Vitro Cellular and Developmental Biology, vol. 45, no. 5, pp. 583-590, 2009.

[10] E. H. Park, H. Bae, W. T. Park, Y. B. Kim, S. C. Chae, and S. U. Park, "Improved shoot organogenesis of gloxinia (Sinningia speciosa) using silver nitrate and putrescine treatment," Plant Omics Journal, vol. 5, no. 1, pp. 6-9, 2012.

[11] J. L. Pang, L. L. Wang, J. Q. Hu, and H. M. Liang, "Effect of gibberellin on direct regeneration of floral buds from young flower buds in Sinningia speciosa Hiern," Acta Biologiae Experimentals Sinican, vol. 37, no. 3, pp. 241-246, 2004.

[12] J. L. Pang, L. L. Wang, J. Q. Hu, T. H. Xiang, and H. M. Liang, "Synergistic promotion of gibberellin and cytokinin on direct regeneration of floral buds from in vitro cultures of sepal segments in Sinningia speciosa Hiern," In Vitro Cellular and Developmental Biology, vol. 42, no. 5, pp. 450-454, 2006.

[13] T. Murashige and F. Skoog, "A Revised medium for rapid growth and bio assays with tobacco tissue cultures," Physiologia Plantarum, vol. 15, no. 3, pp. 473-497, 1962.

[14] L. Burgos and N. Alburquerque, "Ethylene inhibitors and low kanamycin concentrations improve adventitious regeneration from apricot leaves," Plant Cell Reports, vol. 21, no. 12, pp. 1167-1174, 2003. 
[15] S. K. Naik and P. K. Chand, "Silver nitrate and aminoethoxyvinylglycine promote in vitro adventitious shoot regeneration of pomegranate (Punica granatum L.)," Journal of Plant Physiology, vol. 160, no. 4, pp. 423-430, 2003.

[16] G. L. Chi, E. C. Pua, and C. J. Goh, "Role of ethylene on de novo shoot regeneration from cotyledonary explants of Brassica campestris ssp. pekinensis (Lour) olsson in vitro," Plant Physiology, vol. 96, no. 1, pp. 178-183, 1991.

[17] A. K. M. Mohiuddin, M. K. U. Chowdhury, Z. C. Abdullah, and S. Napis, "Influence of silver nitrate (ethylene inhibitor) on cucumber in vitro shoot regeneration," Plant Cell, Tissue and Organ Culture, vol. 51, no. 1, pp. 75-78, 1997.

[18] Y. Akasaka-Kennedy, H. Yoshida, and Y. Takahata, "Efficient plant regeneration from leaves of rapeseed (Brassica napus L.): The influence of $\mathrm{AgNO}_{3}$ and genotype," Plant Cell Reports, vol. 24, no. 11, pp. 649-654, 2005.

[19] V. Kumar, A. Ramakrishna, and G. A. Ravishankar, "Influence of different ethylene inhibitors on somatic embryogenesis and secondary embryogenesis from Coffea canephora P ex Fr," In Vitro Cellular and Developmental Biology, vol. 43, no. 6, pp. 602-607, 2007. 


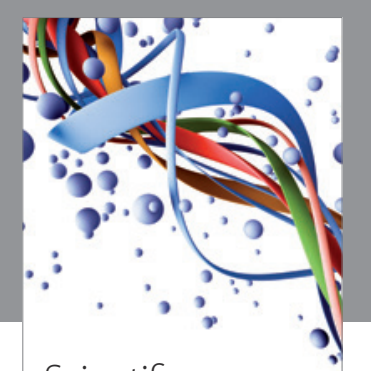

Scientifica
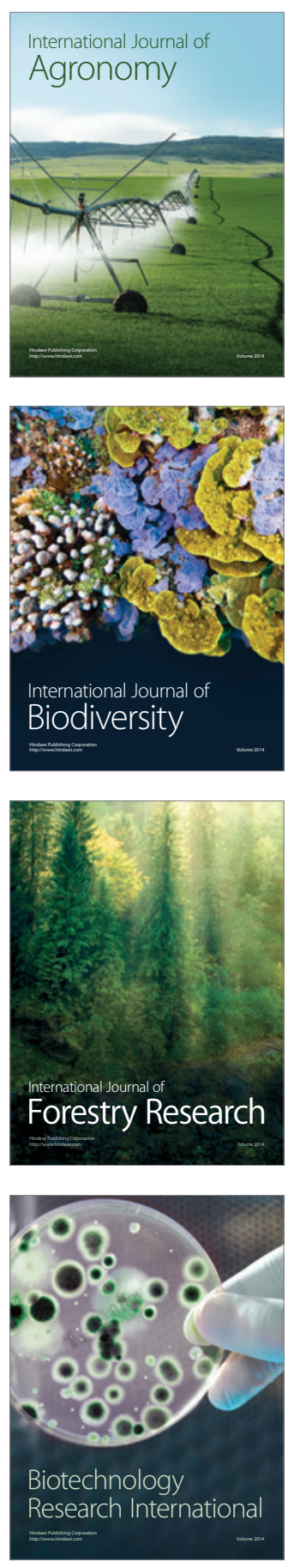
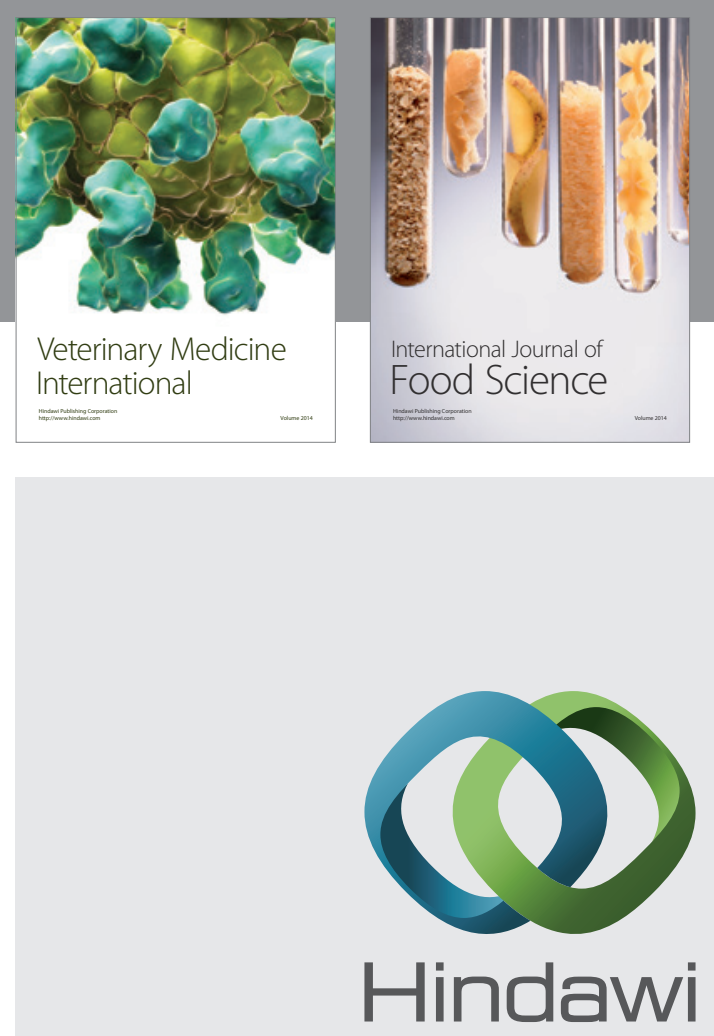

Submit your manuscripts at

http://www.hindawi.com
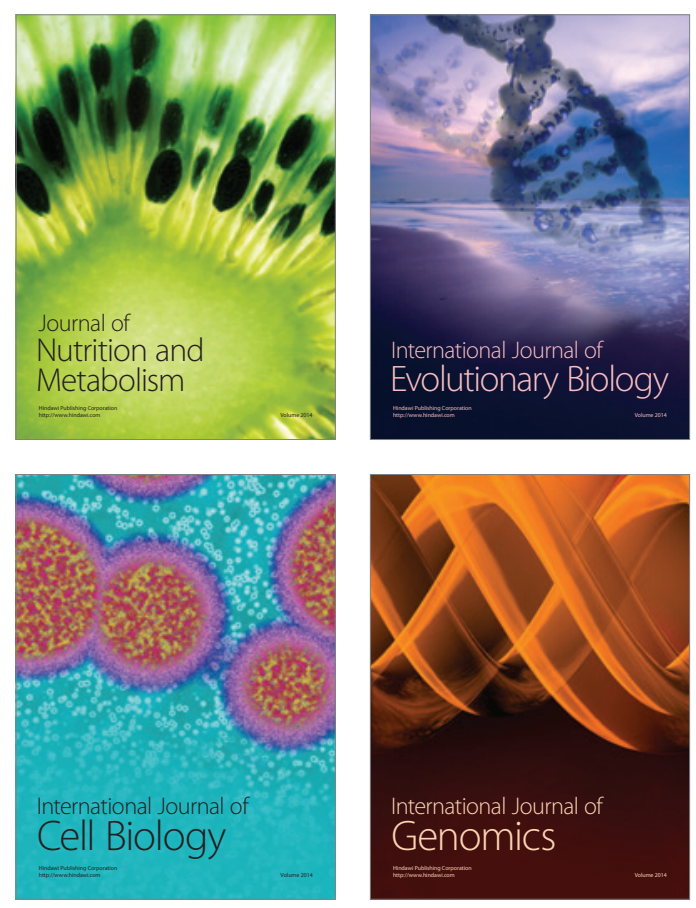
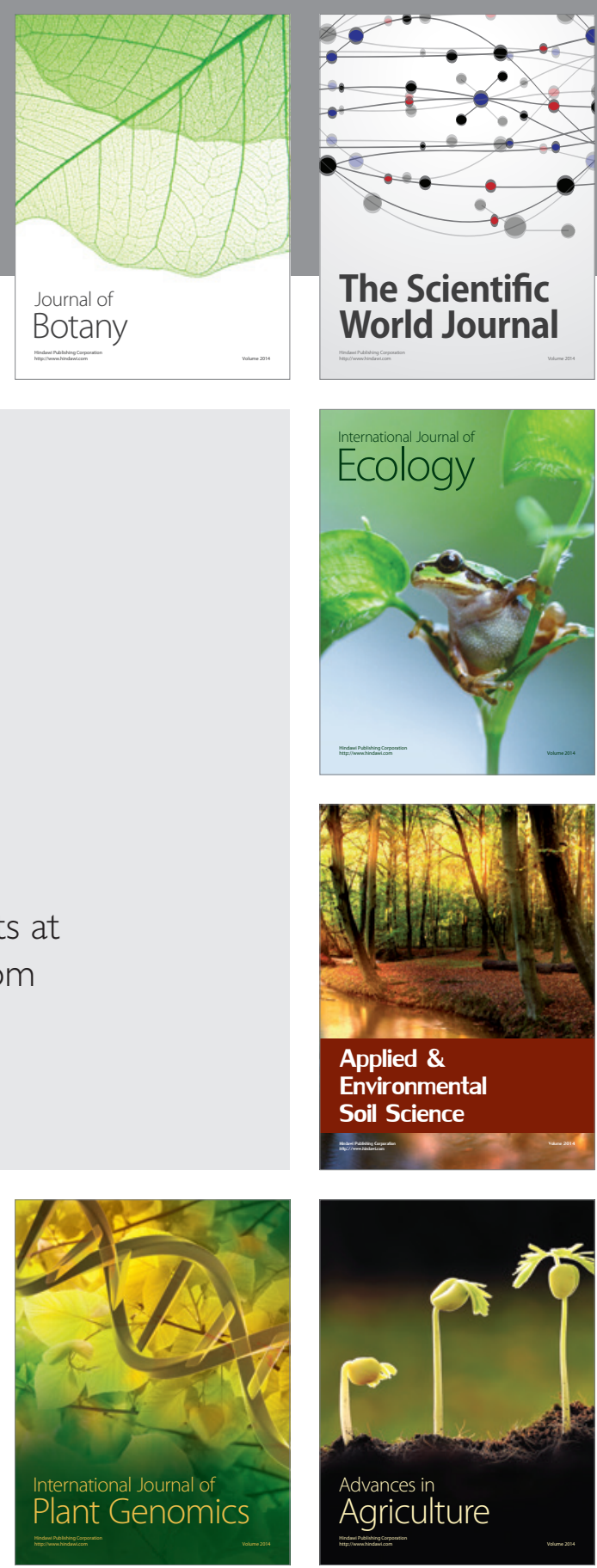

The Scientific World Journal
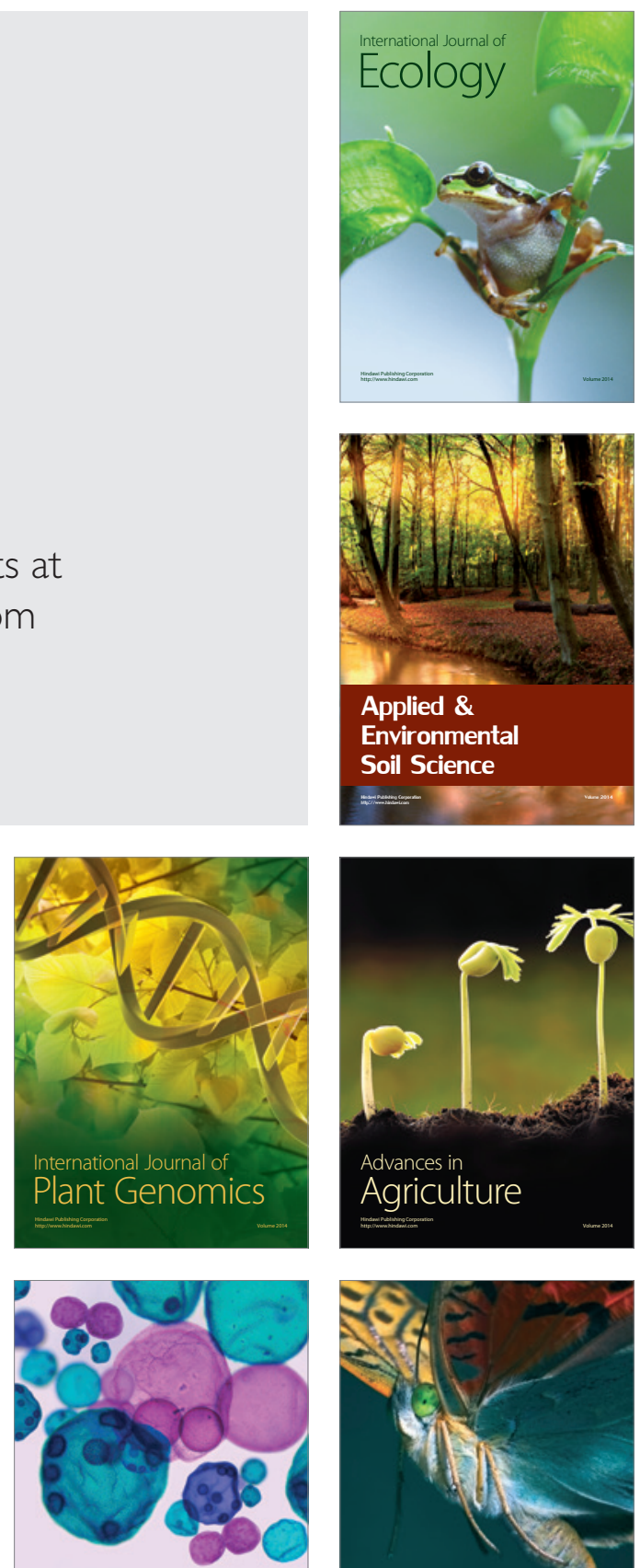

International Journal of Microbiology

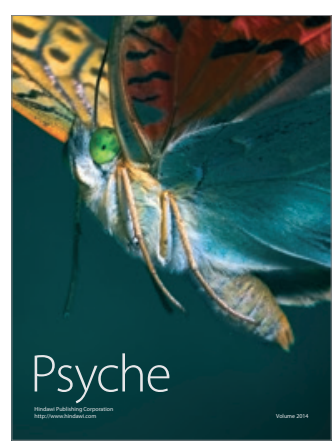

